\title{
SUSTAINABLE REgIONAL LEGAL PRACTICE: THE IMPORTANCE OF ALLIANCES AND THE USE OF INNOVATIVE INFORMATION TECHNOLOGY BY LEGAL PRACTICES IN REgIONAL, RURAL AND REMOTE QUEENSLAND
}

\section{Caroline Hart*}

Recent reports into legal services in regional, rural and remote Queensland indicate that the supply of legal practitioners is insufficient to provide adequate legal services. This paper draws on the results of thirty in-depth interviews with partners (and directors of incorporated legal practices) on the topic of sustainable regional, rural and remote legal practice, with reference to business management practices. This paper focuses on the use of informal alliances between practitioners, and their use of innovative information technology in an effort to deal with the insufficiency of qualified legal staff.

\section{INTRODUCTION}

Access to legal services within regional, rural and remote ('RRR') areas of Queensland is reliant upon the sustainability of law practices. The Queensland Law Society has identified a shortage of lawyers in regional, rural and remote Queensland. ${ }^{1}$ A recent (July 2009) study by the Law Council of Australia

\footnotetext{
* Lecturer (Law), University of Southern Queensland; PhD Student. I would like to acknowledge the contributions of a number of people who have greatly assisted with this article: Firstly, the generosity of those legal practitioners who so willingly gave of their time and experience during our interviews; also the guidance and support of Professor Reid Mortensen and Associate Professor Retha Wiesner in carrying out this research; and $\mathrm{Mr}$ Anthony E Davis, Partner at Hinshaw \& Culbertson, LLP New York and Lecturer, Columbia University School of Law for his contributions on the literature on legal practice.

${ }^{1}$ Glenn Ferguson, 'Bush Lawyers: The Problem Facing Regional and Rural Queensland' (2004) 24(11) Proctor 8.
} 
found that 43 per cent of principals (managing practitioners) throughout Australia do not have sufficient lawyers to service the legal needs of their client base ${ }^{2}$ and 36 per cent of the respondents do not intend to be practising beyond the next five years. ${ }^{3}$ That study also found that demand for professional services in RRR Australia is generally greater than supply; ${ }^{4}$ and that the supply of legal practitioners providing legal aid services is also declining. ${ }^{5}$ This is resulting in a constrained ability to provide justice services to RRR communities. ${ }^{6}$

Earlier research studies carried out in $1998^{7}$ showed a withdrawal of legal practitioners from legal aid in RRR areas; ${ }^{8}$ and in $2004^{9}$ it was concluded 'that professional services are difficult to attract and retain in nonmetropolitan areas, irrespective of whether a region is in decline or growth'. ${ }^{10}$ Over the next five years, RRR Queensland is likely to continue to experience a significant decline in access to legal services.

${ }^{2}$ Law Council of Australia and the Law Institute of Victoria, Report into the Rural, Regional and Remote Areas Lawyers Survey (2009) 5.

${ }^{3}$ Ibid.

${ }^{4}$ Human Rights and Equal Opportunity Commission, National Inquiry into Rural and Remote Education (Australia): Emerging Themes March 2000; Anthony Herrington and Jan Herrington, 'Using the Internet for Professional Development: The Experience of Rural and Remote Professionals' (2006) (Paper presented at the $23^{\text {rd }}$ Annual ASCILITE Conference: Who's Learning? Whose Technology?, 2006). Both sources cited in Recruitment and Retention Working Group, Law Council of Australia, Recruitment and Retention of Legal Practitioners to Rural, Regional and Remote Areas Strategy: Discussion Paper (September 2009), 5.

5 John Dewar et al, 'Griffith Legal Aid Report: The Impact of Changes in Legal Aid on Criminal and Family Law Practice in Queensland' (Research Report commissioned by the Queensland Law Society and the Family Law Practitioners' Association, 1998) as cited in the Law Council of Australia and the Law Institute of Victoria, above n 3, 90-1.

${ }^{6}$ Recruitment and Retention Working Group, Law Council of Australia, above n 4, 5.

${ }^{7}$ Dewar et al, above $n 5$.

${ }^{8}$ Ibid.

9 Jennifer Waterhouse and Neal Ryan, 'Retention of Professional Services in Regional Queensland: Preliminary Research Component' (Report to the Regional Communities Engagements, Department of the Premier and Cabinet, Queensland University of Technology, 2004).

${ }^{10}$ Ferguson, above n 1,8 . 
These are issues that have long been identified by the legal profession and frequently commented upon through professional journals. ${ }^{11}$

There have also been a number of other studies on both the shortage of legal practitioners in RRR areas and the nature of RRR legal practice in Britain ${ }^{12}$ and the USA, ${ }^{13}$ mirroring similar issues.

This paper, drawing from qualitative data gathered from 30 semi-structured interviews, confirms some of the key issues and some of the opportunities experienced by RRR legal practitioners in their day-to-day working lives. The comments below, drawn from the interviews, give an indication of the diversity of issues that practitioners face, including the changing demographics of the workforce:

Solicitors are ageing. They all have more work than they can handle. I can turn away work every day. (Sole practitioner)

There's not a lot of interest in buying a practice out bush. The upside is that there are truckloads of work - you're not fighting for work. (Sole practitioner)

It's a new generation. They want more interaction; updating ... modelling on Facebook. The employed solicitors - most are under 30. Young solicitors don't like the phone. (Partner)

There aren't any new opportunities in the law. (Partner)

${ }^{11}$ John Anderson, 'Re-embracing the Bush' (2000) 12(1) Sydney Papers 48; Rachel Castles, 'Recruitment and Retention of Young Lawyers in Remote, Rural and Regional Queensland' (2003) 23(3) Proctor 32; Simon Creek, 'An Articles Year in the South-West' (1999) 26(4) Brief 11; Ferguson, above n 1; Josephine Pepe 'An Articles Year in Northam' (1999 26(4) Brief 9; Anita Rose-Innes 'Rural Legal Services under Spotlight' (2001) 75(1) Law Institute Journal 50; Teresa Russell, 'Across the Great Divide' (2008) (386) Lawyers Weekly 26; and Natalie Siegel, 'Bush Courts of Remote Australia' (2002) 76(10) Australian Law Journal 640.

${ }^{12}$ Kim Economides and Mark Blacksell, 'The Spatial Analysis of Legal Systems: Towards a Geography of Law?' (1986) 13(2) Journal of Law \& Society 161-81, and Alex Franklin and Robert G Lee, 'The Embedded Nature of Rural Legal Services: Sustaining Service Provision in Wales' (2007) 34(2) Journal of Law \& Society 218.

${ }^{13}$ Donald D Landon, 'Clients, Colleagues, and Community: The Shaping of Zealous Advocacy in Country Law Practice' (1985) 4 American Bar Foundation Research Journal 81-111; Leslie C Levin, 'Preliminary Reflections on the Professional Development of Solo and Small Law Firm Practitioners' (2002) 70 Fordham Law Review 847-900. 
Globally, the practice of law is changing. ${ }^{14}$ The drivers of this change are: the globalisation of economies; ${ }^{15}$ the increased access to information technology; ${ }^{16}$ the changing demands and demographics of the work force; ${ }^{17}$ the changing role of lawyers from being advisors to being providers of information; ${ }^{18}$ and the changing demands of clients from being passive to being more actively engaged. Clients have access to legal information through information technology ${ }^{19}$ and have a perception of how a lawyer should behave - knowledge gleaned through the media. ${ }^{20}$

The aggressive and highly leveraged model of law put forward in the economic boom of the $1980 \mathrm{~s}$ and proposed in the $1990 \mathrm{~s}^{21}$ needs to be revisited in order to provide a model for sustained legal practice.

The forces of both environments - the micro-regional environment ${ }^{22}$ and the macro-national/global environment — are radically shaping and changing the landscape of regional legal practice. The forces are, for some RRR legal practitioners, dark and frightening; for others the forces are offering opportunities for growth and success. The question that forms the basis of this research is: how and why do some RRR legal practices not only survive but also grow and profit, while other practices dwindle and disappear?

\footnotetext{
${ }^{14}$ Richard Susskind, The Future of Law: Facing the Challenges of Information Technology (Oxford University Press, 1996); Richard Susskind, The End of Lawyers: Rethinking the Nature of Legal Services (Oxford University Press, 2008); Thomas D Morgan, The Vanishing American Lawyer (Oxford University Press, 2010); Stephen Mayson, Law Firm Strategy: Competitive Advantage and Valuation (Oxford University Press, 2007); and Laura Empson (ed), Managing the Modern Law Firm: New challenges, New Perspectives (Oxford University Press, 2007).

${ }^{15}$ David Wilkins, 'Globalisation, Technology and the Legal Profession' Mass Tort Litigation Blog (13 August 2010) <http://lawprofessors.typepad.com/mass_tort_litigation/2010/08/ david-wilkins-on-globalization-technology-and-the-legal-profession.html $>$.

${ }^{16}$ Susskind, The Future of Law, above n 14, and Susskind, The End of Lawyers?, above n 14.

${ }^{17}$ Empson, above $\mathrm{n} 14$.

${ }^{18}$ Susskind, The Future of Law, above n 14, and Susskind, The End of Lawyers?, above n 14. Morgan, above n 14.

${ }^{19}$ Susskind, The End of Lawyers?, above n 14.

${ }^{20}$ Wilkins, above $\mathrm{n} 15$.

21 David H Maister, Managing the Professional Service Firm (Maxwell Macmillan International, 1993).

${ }^{22}$ The 'micro-environment' refers to what Donald D Landon, Country Lawyers: The Impact of Context on Professional Practice (Praeger Publishers, 1990) calls 'the containing community'.
} 
Common to both worlds of legal practice (urban practice and RRR practice) is that every legal practice is in competition for clients and in competition to attract suitable legal staff to service the needs of its clients. ${ }^{23}$

Law is both a profession and a business. 'The market-place in which they [lawyers] now operate is a far cry from the rarefied profession they thought they were joining. ${ }^{24}$ In many cases the changes are difficult to accept, as echoed in the comments of one RRR legal practitioner below:

Litigation is getting nasty. The niceties don't apply... I imagine it's worse in the city. The collegiality has disappeared ... decreased. It's about making a buck. You want to make a living ... but some lawyers are driven by financial maximisation. The impact of this is on relations between solicitors. (Partner)

'In the pressurized legal market-place, all the signs are now indicating that sound management is not a luxury; it is a perquisite for solvency. ${ }^{25}$

How legal practitioners deal with the change, whether they adapt or not, will be a matter for each individual. Equally, how lawyers view the current environment and opportunities for their practice is also a matter for each individual.

This paper acknowledges the context of change (occurring globally) and the context of the community (present within regional Australia). However, the primary focus of this paper is on those factors enabling adaptation that are within the control of individual legal practitioners. In particular, the paper focuses on two innovative practices readily (and comparatively cheaply) available to legal practices that will enable adaptation to the changing external environment: Firstly the use of strategic alliances; and, secondly, the innovative use of information technology.

\footnotetext{
${ }^{23}$ Mayson, above n 14, 32 and Susskind, The Future of Law, above n 14, 29.

${ }^{24}$ Mayson, above n 14, 39.

${ }^{25}$ Ibid 233.
} 


\section{The Research Context}

\section{A Methodology}

This paper is based on doctoral research into the question, 'how and why are RRR Queensland legal practices sustainable?' It begins with the hypothesis that legal practitioners can improve sustainability through the use of certain business management practices. These include business planning, use of information technology, marketing, and people management practices.

The research is based on 30 two hour semi-structured interviews ${ }^{26}$ with principals and director ${ }^{27}$ of RRR legal practices in Queensland. The research also relies on legal profession literature and business management literature from Australia, the United States and England. Further interviews are still being conducted to improve the quality of data.

The semi-structured interviews included questions on business management practices, and questions relating to the demographics of the legal practitioner (principal or director) and the demographics of the legal practice. In three instances, legal practices nominated practice managers and information technology managers to be involved. Contact with all participants will continue for the duration of the research.

There are limitations on how the data can be used, given the small sample. ${ }^{28}$ However, as the basis of an exploratory research study, the qualitative data is rich and provides an opportunity for insight into life as a RRR principal that might not otherwise be available.

\footnotetext{
${ }^{26}$ The research study has been designed and carried out with reference to the qualitative research literature including: Robert K Yin, Case Study Research: Design and Methods (Sage Publications, revised ed, 1989); A Michael Huberman and Matthew B Miles, The Qualitative Researcher's Companion (Sage Publications, 2002); David Silverman, Doing Qualitative Research: A Practical Handbook (Sage Publications, $2^{\text {nd }}$ ed, 2005) and Lyn Richards, Handling Qualitative Data: A Practical Guide (Sage Publications, 2005).

${ }^{27}$ Directors of incorporated legal practices as defined under the Legal Profession Act 2007 (Qld).

${ }^{28}$ Based on data from the Queensland Legal Services Commissioner (2008), there are 1363 legal practices in Queensland. From this data and based on the adapted ARIA index, there are 271 'regional, rural and remote' legal practices in Queensland. In other words 19.9 per cent of legal practices in Queensland can be termed 'regional, rural and remote'. One hundred and sixty of these RRR legal practices (59 per cent of the RRR legal practices) were contacted through the research study. Of the 160 RRR legal practices contacted, 30 RRR legal practices (or 18.8 per cent) responded.
} 


\section{B Defining RRR Queensland}

Legal practices were selected to provide a broad range of coverage throughout Queensland. They were selected from legal practices in Atherton, Port Douglas, Cairns and Townsville in Far North Queensland; from practices in Mount Isa, Roma and Chinchilla in Western Queensland; from practices in Biloela and Blackall in Central Queensland; and from practices in Kingaroy, Goondiwindi and Dalby in South Queensland. The legal practices were also selected according to structure, to provide coverage of: sole practices, partnerships and incorporated legal practices.

The research study refers to the Accessibility/Remoteness Index of Australia ('ARIA') ${ }^{29}$ in which areas are indexed according to their access to goods and services and opportunities for social interaction. The classes include: 'highly accessible' in which there is relatively unrestricted access to a wide range of goods and services and opportunities for social interaction; 'accessible' in which there are some restrictions to the accessibility of some goods, services and opportunities for social interaction; 'moderately accessible' in which there is significantly restricted accessibility of goods, services and opportunities for social interaction; 'remote' in which there is very restricted accessibility of goods, services and opportunities for social interaction; and finally, 'very remote' in which there is very little accessibility of goods, services and opportunities for social interaction. ${ }^{30}$

\footnotetext{
${ }^{29}$ The University of Adelaide, Welcome to the GISCA (17 December 2009) <www.gisca. adelaide.edu.au>.

${ }^{30}$ Ibid.
} 


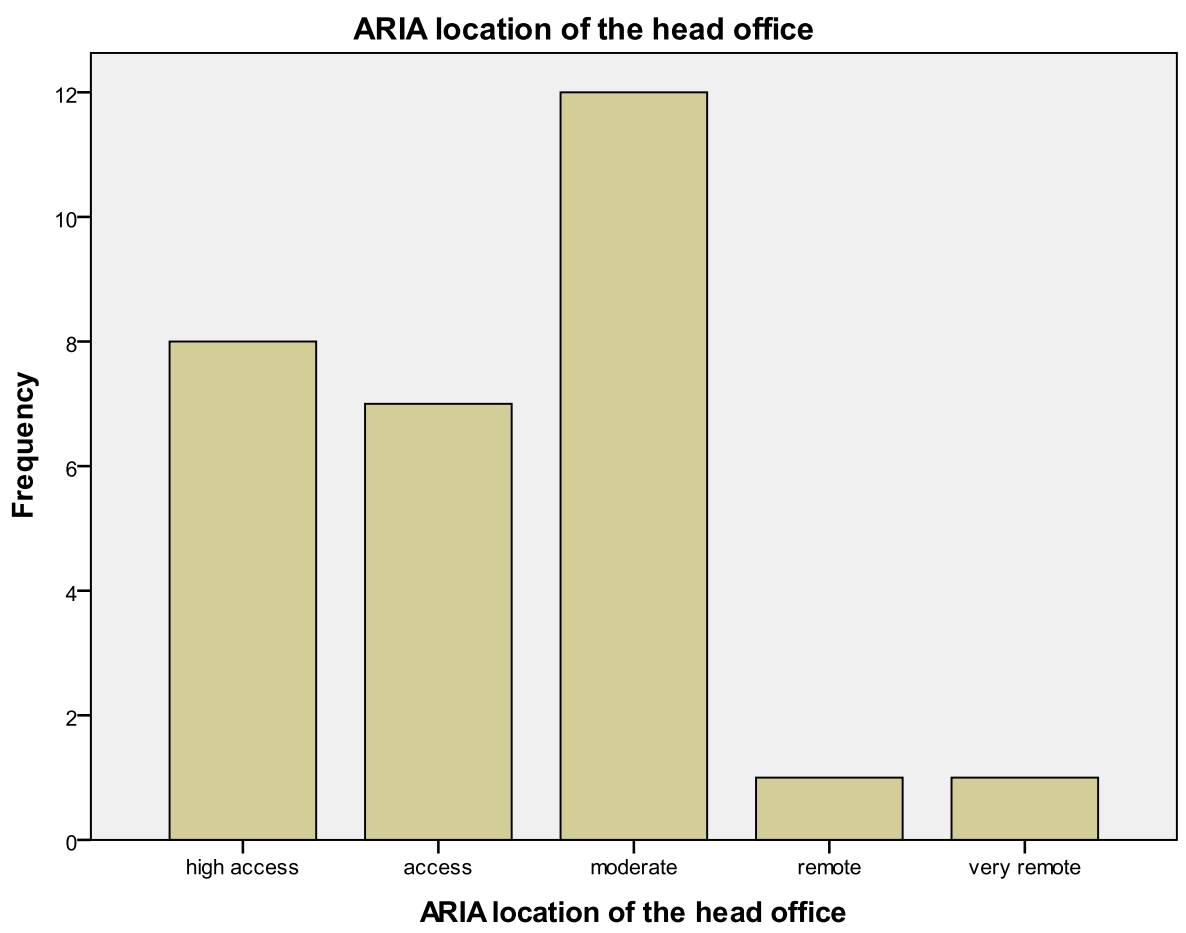

Use of the ARIA Index will be further adapted to take into account limitations in its application to defining 'RRR Queensland'. For example, Dalby in Western Queensland is classified as High Access However, it was clear from the legal practitioner's point of view that the legal practice was in a 'rural location'. The use of the ARIA index will be adapted to reflect a location's population, access to courts (magistrate, district and supreme), and access to members of the legal fraternity (number of solicitors and barristers).

\section{Diversity of Regions}

The diversity of regional Queensland is revealed through the statistics collected by the Queensland Treasury's Office of Economic and Statistical Research. ${ }^{31}$ The literature confirms that the issues facing RRR Australia (including Queensland) cannot be generalised from one RRR location to

\footnotetext{
${ }^{31}$ See the Queensland Government Office of Economic and Statistical Research (July 24, 2010) $<$ www.oesr.qld.gov.au.>. The OESR divides Queensland into Local Government Areas and provides statistical analysis of population, economics, housing and employment.
} 
another. Giddings, Hook and Nielsen ${ }^{32}$ note the diversity of RRR areas, and Eaton identifies the legal needs of clients as also being characterised by diversity. ${ }^{33}$ Landon in his studies in the $\mathrm{US}^{34}$ and Economides in his studies in England ${ }^{35}$ also confirm the diversity of the 'containing community' in which the RRR lawyer practises.

What is apparent from the Queensland RRR statistical information is that there are areas of both population growth and decline and that there are areas of enormous economic development. However, each area is distinct in terms of access to services and goods, and infrastructure. This doctoral research uses the ARIA index as a broad gauge for determining the environment in which the legal practice is operating.

\section{A Definition of 'Sustainable'}

It has been difficult to find a clear and complete definition of what it is to be 'sustainable' within a business context. It is necessary to identify criteria relevant to the term so that some attempt can be made to measure whether or not a legal practice is 'sustainable'.

Mayson $^{36}$ refers to 'sustainable' and 'sustainability' consistently and with great care in Law Firm Strategy. However he does not expressly define either 'sustainability' or 'sustainable' as he does with other terms. ${ }^{37}$ The absence of a clear definition here and throughout the business and management literature may be deliberate.

\footnotetext{
32 Jeff Giddings, Barbara Hook and Jennifer Nielsen, 'Legal Services in Rural Communities: Issues for Clients and Lawyers' (2001) 26(2) Alternative Law Journal 57.

${ }^{33}$ Kaz Eaton, 'One Size Does Not Fit All: Legal Needs of Women in Regional, Rural and Remote Australia' (2001) 26(2) Alternative Law Journal 64.

${ }^{34}$ Donald D Landon, Country Lawyers: The Impact of Context on Professional Practice (Praeger Publishers, 1990); Donald Landon, 'Clients, Colleagues, and Community: The Shaping of Zealous Advocacy in Country Law Practice' (1985) 4 American Bar Foundation Research Journal 81; and Donald D Landon, 'Lawyers and Localities: The Interaction of Community Context and Professionalism' (1982) 2 American Bar Foundation Research Journal 459.

${ }^{35}$ Kim Economides and Mark Blacksell, 'The Spatial Analysis of Legal Systems: Towards a Geography of Law?'(1986) 13(2) Journal of Law and Society 161-81; and Kim Economides, Mark Blacksell and Charles Watkins, Justice outside the City: Access to Legal Services in Rural Britain (Wiley, 1991).

${ }^{36}$ Mayson, above $\mathrm{n} 14$.

${ }^{37}$ Ibid 351.
} 
Mayson does, however, state that creation, sustainability and longevity are treated as different dimensions of an organisation:

Once an organisation exists, longevity refers to the characteristics that determine the period of time for which it is sustained, as distinct from the attributes of organisation that sustain it. It is the merging of creation, sustainability and longevity that combine to determine the persistence of the firm itself. ${ }^{38}$

For the purposes of the present research study, 'longevity' is included in the definition of 'sustainability' because it gives some measurable (not necessarily sufficient) indication that the legal practice has continued.

Mayson also refers to degrees of sustainability, in terms of a law practice either being of 'high sustainability' or 'low sustainability'. ${ }^{39}$ In his discussion, he recommends that to remedy 'low sustainability', investment should be made in the drawing out of a sympathetic normative environment. ${ }^{40}$ This suggests the possible inclusion of a 'normative environment' as being one of the elements of sustainability. (This element is discussed below.)

In the business management literature, the term 'sustainable' has been used interchangeably with 'successful'and has been coupled with it. Although there may be some overlap of meaning between the terms - for example, Mayson states that a law practice needs to be not only successful, but also sustainable $^{41}$ - the implication is that to be 'sustainable' is to be something (slightly) more than successful.

There is also acknowledgement from the business management literature that 'success' is a subjective concept. A person may have a vision of what 'success' is for them - for example, that the person should enjoy a happy work-life balance - and that vision may be fulfilled. However, when viewed from an outside point of view, that 'success' becomes questionable because, for example, the rate of profit is dwindling. ${ }^{42}$

\footnotetext{
${ }^{38}$ Ibid 237.

${ }^{39}$ Ibid 340-2.

${ }^{40}$ Ibid 341.

${ }^{41}$ Ibid 237.

${ }^{42}$ Mike Simpson, Nicki Tuck and Sarah Bellamy, 'Small Business Success Factors: The Role of Education and Training' (2004) 46(8) Education + Training, 481-91.
} 
Therefore, based on an amalgamation of the economic literature, the business management literature and the legal professional literature, with some reference to the systems literature, the following elements of a definition of 'sustainability' are proposed.

Firstly, there must be longevity (or continuity) of practice. Although Mayson expressly distinguishes 'longevity' from 'sustainability', he does so on the grounds that it is 'a different dimension' of the organisation - not on the grounds that it is unrelated.

For this research study, 'longevity' provides a much needed baseline measurement from which 'sustainability' practices can be gauged. Mayson adds, however, that longevity '... is 'more than the avoidance of cessation, it is the continuation of active, productive life'. ${ }^{43}$ Again, this emphasises Mayson's vision that there are degrees to 'sustainability'.

Mayson states that 'longevity does not refer to [the practice's] immortality, but rather to its durability or continuance.... ${ }^{44}$ This then can take into account the fact that some legal practitioners have an 'exit strategy', and indeed, a number of RRR principals spoke of such a strategy.

\footnotetext{
${ }^{43}$ Mayson, above n 14, 237 citing Montuori, 'Organisational Longevity - Integrating Systems Thinking, Learning and Conceptual Complexity’ (2000) 13(1) Journal of Organisational Change Management 61, 69.

${ }^{44}$ Ibid 237.
} 


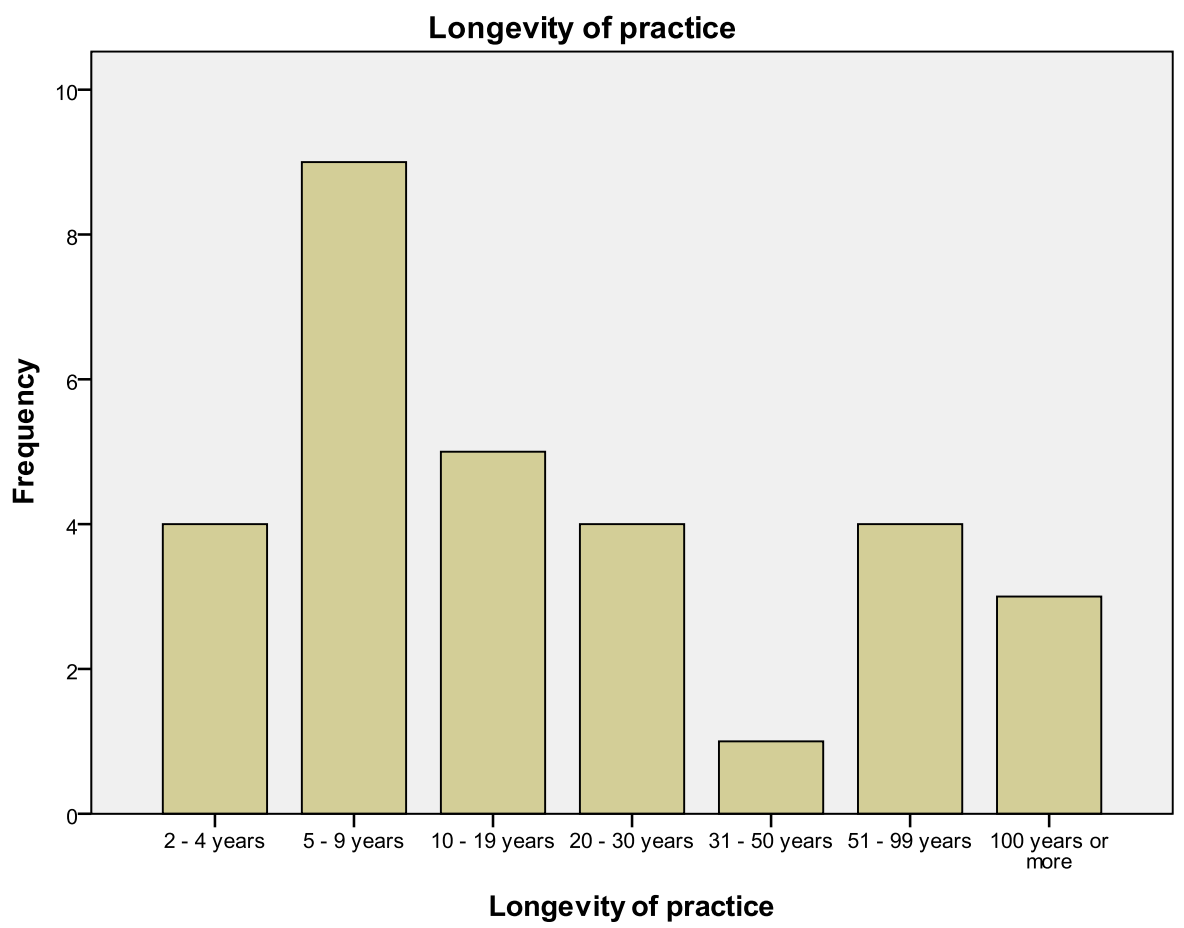

Secondly, there must be profit or solvency. This is at the heart of the economist John Hick's concept of value and capital. He states: 'The purpose of income calculations ... is to give people an indication of the amount which they can consume without impoverishing themselves. ${ }^{, 45}$

The economic literature on 'commercial sustainability' provides a limited, narrower definition:

[A] person's maximum consumption should not be greater than the level of income that does not reduce the initial level of capital. Such a concept of maximising income flows without reducing asset stocks is the key to many concepts of sustainability... ${ }^{46}$

\footnotetext{
45 John R Hicks, Value and Capital: An Inquiry into Some Fundamental Principles of Economic Theory (Clarendon Press, $2^{\text {nd }}$ ed, 1946) 172.

${ }^{46}$ Matthew Clark and Sardar M N Islam, Contributions to Economic Analysis: Economic Growth and Social Welfare: Operationalising Normative Social Choice Theory (Elsevier, 2004) 183 .
} 
Jacobsen (a legal practitioner) provides the following, very brief, definition of sustainability: 'to keep solvent'. ${ }^{47}$ Munro $^{48}$ states that the benefits of a definition that relates to 'benefits exceeding or balancing costs' may be more easily measurable (although it will still be affected by many variables).

The requirements of mere profit, or continued profit alone are definitions that are too narrow for this research study. A narrow definition does not take into account 'costs' that may not be apparent, including: a miserable working environment or a high staff turnover. Given that the context (and justification) of this research relates to the critical issue facing RRR legal practices of staff recruitment and retention, the definition of 'sustainability' must incorporate other criteria at least. It must incorporate, for example, an element that relates to 'a working environment'. Elements other than profit are needed.

The pursuit of a broader definition is supported by Mayson's references to 'high sustainability' and 'low sustainability', in which he comments that a legal practice driven purely on profit may be 'sustainable', but not nearly as highly sustainable as it could or ought to be.

The narrow definition does not take into account either 'the normative environment' in which 'sustainability' is occurring or its resources. These resources include clients to create the income and legal staff to service the needs of clients.

Thirdly, there must be 'resources' to sustain the legal practice. 'Resources' in this context is a reference to 'available clients' and 'access to legal staff'. And these resources must be renewable to take into account the effects of time and aging on these mortal resources.

Fourthly, growth must be considered. Growth is seen as essential in order to allow professional firms to diversify and to meet changing client needs. ${ }^{49}$ Management research shows that business structures that grow manage to

\footnotetext{
${ }^{47}$ David Jacobsen, 'Measuring the Benefits of Sustainable Best Practice' (2001) 21(7) Proctor 17.

${ }^{48}$ David Munro, 'Sustainability: Rhetoric or Reality?' in Thaddeus Trzyna (ed), A Sustainable World: Defining and Measuring Sustainable Development' (International Union for Conservation of Nature, 1995).

${ }^{49}$ Heidi Gardner, Timothy Morris and Narasimhan Anand, 'Your Expertise: Developing New Practices: Recipes for Success' in Laura Empson (ed), Managing the Modern Law Firm: New Challenges, New Perspectives (Oxford University Press, 2007) 65. Growth is also discussed by Maister, above $\mathrm{n} 21$, and by Mayson, above n 14, 32-4.
} 
survive better than business structures that do not grow. ${ }^{50}$ Maister $^{51}$ and Mayson $^{52}$ both state that growth provides the structure to attract the staff and provide a path of progression; and to ensure that sufficient/suitable staff are available to service the clients. ${ }^{53}$ The extent to which the growth can occur, however, is dependent upon the ability to expand and manage through leveraging or gearing the renewable resources (clients and legal staff). ${ }^{54}$

The systems literature, however, views 'growth' with caution.

The longer people sustain a social, economic, or ecological system in its growth phase, the sharper, harder, and more destructive its ultimate breakdown will be. ${ }^{55}$

Homer-Dixon proposes an adaptive cycle that can be represented as a threedimensional entity that rises and falls and rises again. ${ }^{56}$ Charles Handy uses the Sigmoid Curve as the descriptor of growth

[The Sigmoid Curve] is the story of a product's life-cycle and of many a corporation's rise and fall.... The secret of constant growth is to start a new Sigmoid Curve before the first one peters out. ${ }^{57}$

The research study will explore the management practices carried out within (and available to) legal practices to assist with identifying opportunities for dealing with the rises and falls.

The idea of 'limits to growth' was the foundation of Brundtland's 'sustainable development'. ${ }^{58}$ While this research does not rely upon an environmental

\footnotetext{
${ }^{50}$ Svante Andersson and Joakim Tell, 'The Relationship between the Manager and Growth in Small Firms' (2009) 4(16) Journal of Small Business and Enterprise Development', 586-98, citing Per Davidsson and Frederic Delmar, 'Tillväxtföretagen i Sverige' (Report, SNS Förlag, 2001).

${ }^{51}$ Maister, above n 21, 6-7.

${ }_{53}^{52}$ Mayson, above n 14, 32-4.

${ }^{53}$ Ibid.

${ }^{54}$ Ibid and Maister above n 21, 3-10.

${ }^{55}$ Thomas Homer-Dixon, The Upside of Down: Catastrophe, Creativity, and the Renewal of Civilization (Text Publishing, 2006) 232.

${ }^{56}$ Ibid 229.

${ }^{57}$ Charles Handy, The Empty Raincoat: Making Sense of the Future (Random House, 1994), $50-1$.

${ }^{58}$ Simon Dresner, The Principles of Sustainability (Earthscan, 2002) 76 discussed the idea of sustainability as having originally emerged out of the 'limits to growth' thinking. This was put forward by Brundtland in her concept of 'sustainable development' as part of the World [Brundtland] Commission on Environment and Development, commissioned by the United
} 
definition of sustainability, the definition acknowledges that growth does not need to be limitless. For the purposes of this research then, the definition needs to incorporate this element.

The complexity of growth and its links to sustainability are also evident from the comments of two RRR legal practice partners, both of whom are in legal practices that registered highly in terms of longevity and performance:

We made the decision to cap it at a certain size; to be selective; and to charge a premium. ... We're focussed on a balanced life. We are able to achieve comfortable returns on our investment in capital and time. We could do five or ten times the work. (Partner)

We're opposed to growth for growth's sake. We would only grow for two reasons: profit and competitiveness. (Partner)

Against the background of the broader systems literature and the grounded experiences of long-term partners, the element of 'growth' is qualified by it needing to be either 'controlled growth', 'managed growth' or 'strategic growth'.

Finally, a complete definition of 'sustainability' should make reference to the environment within the law practice, for reasons mentioned above. Mayson defines the 'normative environment' within the legal practice as 'the overall purpose, concept, culture and climate of the business'. ${ }^{59}$ It 'is the sum of all those influences on the ways in which shared meaning is developed and transmitted within the firm and in which commonly acceptable behavior is framed and enacted' ${ }^{60}$

If human resources providing legal knowledge (in the form of intellectual capital) are one of the primary resources of a legal practice, then, for a legal practice to be sustainable, relationships among the personnel must also be sustained and must have attention given to them. The internal environment is then dependent upon processes relating to these relationships, including dispute resolution mechanisms, partner relations, and protection of values such as 'trust'. Mayson describes this environment as encompassing what ought to happen (the culture) and what actually does happen (the climate) ${ }^{61}$

Nations (1983). The idea of limitations related to the extent of an environment's ability to meet not only present needs but also future needs.

${ }^{59}$ Mayson, above n 14, 47.

${ }^{60}$ Ibid 56.

${ }^{61}$ Ibid. 
As a start, some attempt at measuring this element can be made by rating partner satisfaction, and tracking rates of legal staff retention.

\section{E Factors within the Control of the Legal Practice}

The economic environment in which the legal practice resides, together with the regulatory environment imposed by professional bodies including the Queensland Law Society, the Legal Services Commissioner and the courts, are factors external to the firm and therefore not within the control of the firm. Nevertheless, it is argued that the sustainability of regional legal practice can be maximised if the principals or director of the legal practice give attention to the business management of the legal practice - the internal environment. $^{62}$

This paper considers the use of innovative practices by regional legal practices as methods of seeking to achieve sustainability. In particular the paper looks first at alliances with other legal practices and secondly at the innovative use of information technology.

\section{The InNovative Use of Alliances With Other Legal PRACTICES}

Partnership has been the traditional governance structure through which legal services have been provided. ${ }^{63}$ However, with the greater choice of governance structures available, including incorporated legal practice, ${ }^{64}$ limited liability partnerships, ${ }^{65}$ and multi-disciplinary partnerships, conventional partnerships are in decline. ${ }^{66}$

\footnotetext{
${ }^{62}$ The factors that are within the control of the principals and director of the legal practice include business management practices such as determining: the legal structure of the firm, its links to the profession, its connectedness to the organisations of the immediate community, its use of business planning practices, people management practices and marketing practices, and its use of information technology.

${ }^{63}$ Partnerships are regulated in Queensland by the Partnership Act 1891 (Qld).

${ }^{64}$ Incorporated legal practices and multi-disciplinary partnerships are defined and regulated by the Legal Profession Act 2007 (Qld).

${ }^{65}$ Limited liability partnerships are regulated under the Partnership Act 1891 (Qld), as amended by the Partnership (Limited Liability) Act 1988 (Qld).

${ }^{66}$ Empson, above n 14, 10. Mayson, above n 36, 322 suggests that the rationale for the movement into limited liability partnerships by legal practices in which the number of partners is increasing, is that such structures can provide a degree of limited liability 'within a hybrid that allows the benefits of an incorporated body but with the retained feel... of
} 


\section{A Why 'Partnership' Is So Important to Legal Practitioners}

Empson asserts that partnership as a governance structure for legal practices works because it balances the competing needs of lawyers and clients (and owners) ${ }^{67}$ The needs of lawyers relate to seeking high levels of autonomy ${ }^{68}$ and freedom to exercise independent judgment in order to provide expertise in their work. The needs of the client relate to trusting that the lawyer will focus on service rather than maximising profit. ${ }^{69}$ In this way, partnership satisfactorily balances these needs based on the drive of partners to deliver quality work over and above (but not without reference to) the pursuit of profit .

Partnership, as a governance structure, is also important for other reasons. The legal form of partnership ${ }^{70}$ that includes unlimited liability creates a tension within the partnership. ${ }^{71}$ This tension is relieved, however, through the ethos of partnership ${ }^{72}$ in which 'the interests of the individual are reconciled with those of the collective ${ }^{73}$ This occurs through intense socialisation and the partnership management structure.

\section{B The Partnership Ethos in RRR Queensland}

From the RRR interviews, it is apparent that the partnership ethos exists amongst the legal practices in partnership. Statements relating to the ethos reveal that it is emotionally demanding and that it requires trust and respect:

An action won't proceed unless they look at the benefit of the firm. If there is strong opposition then they will not proceed. If there is a majority then they will go ahead. In a partnership you need to respect the opinions of others. We always have plenty of discussion and take a professional

\footnotetext{
partnership'. The additional argument for the movement towards incorporation is the appeal of 'attracting new external ownership or investment'.

${ }^{67}$ Empson, above n 14, 11.

68 Ibid.

69 Ibid 15: The third need is that of 'the owner' of the partnership (that is, the partners themselves). Empson states that the interests of the owners which are geared towards the generation of income are best served when aligned with the interests of the professionals.

${ }^{70}$ Ibid 13-15. Empson proposes (at page 20) that the legal form of partnership, is based upon its composition by '[a]n elite group, educated and formally recognised by the profession, and bound by unlimited personal liability through regulatory means.'

${ }^{71}$ Ibid 20.

72 Ibid 22.

${ }^{73}$ Ibid.
} 
approach. There is a sense that the partners would die for you. Good partners - they rely on you. If I got sick then they would carry me. We have full insurance - death and disability - but there is the sense that if I couldn't work that they would look after me. I want to leave the firm in a better position than when I came into it! (Partner)

The firm valued clients and partners so highly that they decided to open a branch office [to retain a partner]. For five to ten years the X [location of practice] office was not viable, but has now begun to contribute their share. It carries the country ethos at the coast. It continues the 'country values attitude' into the coast. (Partner)

The partners complement each other, but are opposites. This is very good for business management, but can create tensions. I have rapport and am very understanding. (Partner)

If we have a dispute we talk things through to work through the tensions. We also indulge each other, for example X's [interest]. We also think alike; we share the same values. We have things in common and similar backgrounds. We are in it for the long term. (Partner)

If we felt strongly about it we wouldn't do it or we would compromise. We keep the other partner informed. It's an equal partnership. (Partner)

It's robust and honest; being with the group for a long time. We don't allow dead elephants in the room; they are difficult to deal with. (Partner)

Those principals who had enjoyed longevity in their partnerships also registered highly in terms of implementing mechanisms for dealing with disputes.

\section{Pressures upon Partnership}

Partnership also had to bear the pressure of a range of issues originating both externally and internally to the partnership. Empson considers a range of factors (economic, social and regulatory) that are bringing pressure to bear upon partnership. She expressly states the impact of changing social trends, for example, the shifts in priorities of younger lawyers who are potential partners. $^{74}$

\footnotetext{
${ }^{74}$ Ibid 23.
} 
Within the group of principals and directors interviewed, the pressures were varied and chiefly related to internal forces. The pressures arose from: generational expectations; office romances; financial issues; egos; and adjustments to partnerships after sole practice.

Their values [those of the younger partners] are of different generations; they have different expectations, different work ethic. It's difficult to make a cohesive team, to find a middle ground. For example, for a solicitor review - the salary increase, the issue of pay ... they want that rather than to re-invest in the practice. (Partner)

We were together for 18 years. His wife worked in the practice. He had an affair... he wasn't working - with everything that was going on in his life, he wasn't working effectively. It got difficult with all the relationships. His wife was working at one end of the office; his girlfriend was at the other end of the office. The fact that he wasn't working effectively... And there were negative views in a small town. The other partner and I we couldn't support it all. (Partner)

It is the tough part of practising. I was pissed off with a partner. It was difficult to be CEO. You can't please everyone. I make a decision for the staff - then the partners are upset - and vice versa. I need to make a decision for the firm as a whole. This led to disputes - that they were not looked after. I withdrew from the role ... [T] he hardest part is to work well with partners. ... It's the toughest thing - the egos of lawyers. There are seven different motivations of why we are in partnership. The strongest motivation can outweigh that of another. That can create conflict. The single biggest issue is the firm versus individual issues ... or values... (Partner)

With the partnership - $\mathrm{X}$ has been on his own for so long. It is frustrating; like a marriage. (Partner)

Despite the pressures, Empson comments: 'If partnership is the optimal method of balancing the competing claims of its professionals, owners, and clients, then it is logical to conclude that professional service firms should make every effort to retain partnerships ${ }^{75}$ even to the extent of 'imitating partnership'. ${ }^{76}$

In RRR Queensland, the chief pressure upon partnership does not come from competing governance structures (such as incorporation, that provides

\footnotetext{
${ }^{75}$ Ibid 29.

${ }^{76}$ Ibid.
} 
limitations on liability), but rather from the need to provide appropriate practice areas, to access suitably qualified legal staff, and to service clients.

Does the 'imitation of partnership' offer a model that is suitable for RRR legal practice that will assist in resolving these critical issues in providing legal services?

The next part of the paper considers the existing governance structures in RRR Queensland and how, through the use of alliances, the dilemmas of insufficient legal staff can be dealt with.

D Governance Structures and the Queensland RRR Situation

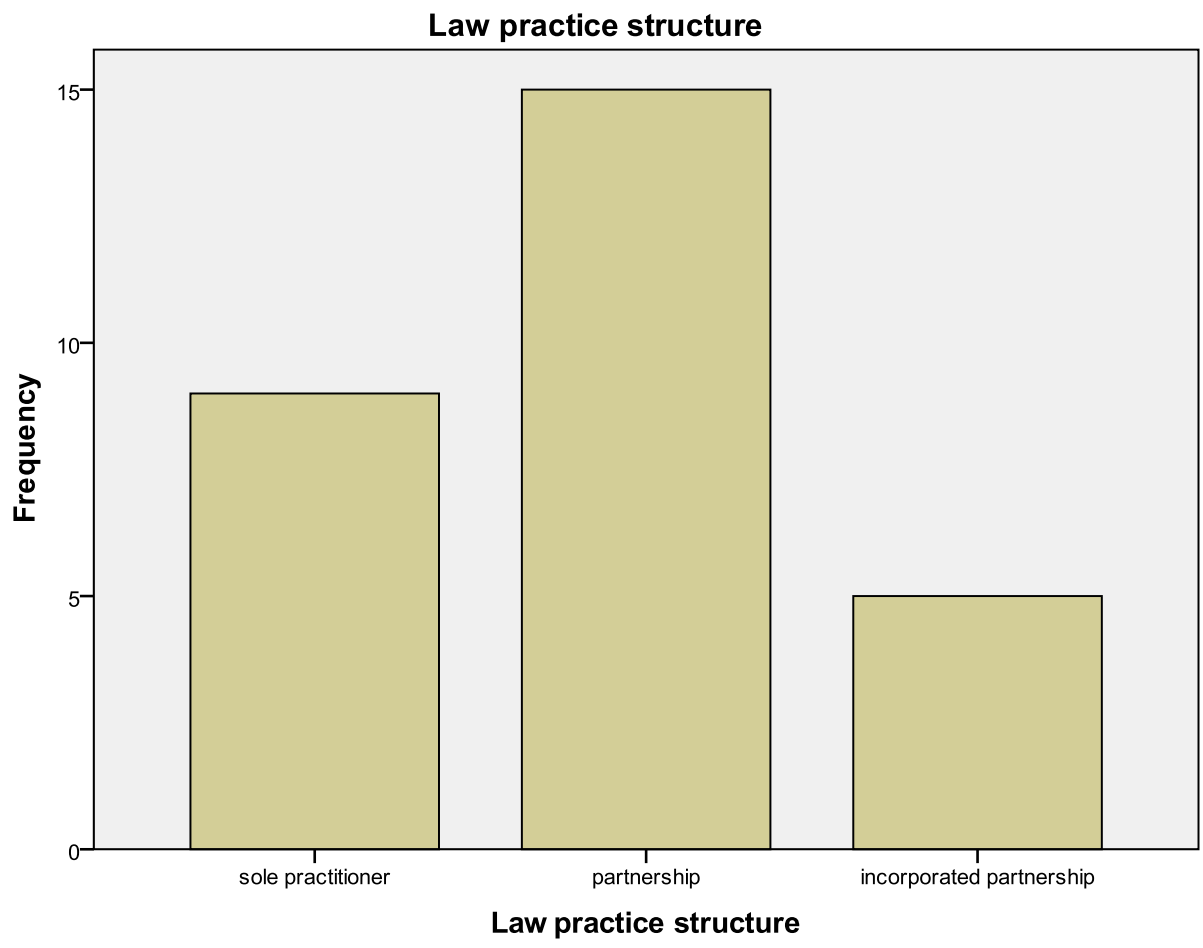




\section{$1 \quad$ Life as a Sole Practitioner}

Sixty-three per cent (172) of RRR practitioners in RRR Queensland practice are sole practitioners. ${ }^{77}$ One hundred and two of those sole practitioners are the only holders of a practising certificate within the law practice.

Of the 30 principals interviewed, nine ( 31 per cent) are sole practitioners. Of these nine, five similarly were the only holders of a legal practising certificate. Based on the exploratory data, a number of points can be raised that compare and contrast the life of the sole practitioner with that of the partner.

\section{Reasons Sole Practitioners Choose to Practise Alone}

A number of sole practitioners deliberately chose sole practice (with or without an employed solicitor) for very specific reasons. Some of the reasons are based on self-knowledge and an acknowledgement of 'the partnership ethos':

I have been approached by another firm to join forces, in a partnership. I said 'no'. There is no benefit. I would make a bad partner ... And you have to have trust!

I would do it as a family business, but never as a partnership. I wouldn't consider a partnership.

Others avoid partnership due to dissatisfaction with previous partnership experiences. Such experiences involved: methods of dispute resolution, lack of trust, ethical issues, and differing values:

I was in a partnership - I had a growing discontentment with my partner's lack of professionalism. He'd had a marriage breakdown; he was a heavy drinker; there were financial implications. I was with X for 19 years. There were some productive years. The best thing I've done was to dissolve the partnership. My life is less stressed; my life has improved. It is a small town; people talk.

The other partner induced me to go into the partnership. We lasted for some years. We split for financial reasons; it didn't work out. The second

\footnotetext{
${ }^{77}$ Based on the 2008 data from the Legal Service Commissioner, the total number of legal practitioners in Queensland is 1363. Based on the adapted ARIA Index, 271 of those practices can be termed to be located in RRR Queensland. Of the 271 RRR legal practices, 172 are practices in which there is one principal. Some of these practices include an employed solicitor. The 2008 data reveal that within 102 of these practices there is only one practising certificate held, and that is by the principal. These 102 practices are indeed operated by a 'sole' practitioner.
} 
partnership ... The cost of running the $[\mathrm{X}]$ practices was prohibitive. I put myself in debt. At the end of three years I said, 'enough'. I said that this was no good, and we parted amicably. I decided never to go into partnership again.

\section{Levels of Stress Associated with Sole Practice}

All of the sole practitioners reported levels of stress associated with legal practice both on the grounds of being a sole practitioner and on the grounds of RRR legal practice. The most common grounds of stress included the inability to get away from the practice to have a holiday; fear of 'being run over by a bus'; regulatory impacts and not being able to adequately comply with them; and the lack of professional colleagues with whom to discuss legal issues:

I'm working harder every day ... how do you operate as a sole practitioner? It's very difficult. You have to look at progression ... The difficulties are that you can't bounce ideas off others ... [T] he ability to work through problems becomes a necessity to keep up with everything - the areas of law... the business... There are areas of law not done because I can't do them. (Sole practitioner)

These comments indicate working conditions that contrast with the less stressful working conditions offered by partnership.

I'm in a partnership because you can get away for a short time; you can consult with another practitioner ... that eases the burden. You can go away. (Partner)

\section{The Forging of Informal Alliances}

A common theme amongst many of the sole practitioners interviewed became evident; it related to their engagement in networks ${ }^{78}$ or alliances. ${ }^{79}$ All of the

\footnotetext{
${ }^{78}$ The Macquarie Dictionary (2001) describes 'networking' as establishing 'social contact with particular people because it is thought that they may prove to be useful'. Much has been written and investigated in the management literature on networking, and on the importance of modern enterprises (of all sizes) in engaging in alliances. Antonia Albani and Jan L G Dietz in their article 'Current Trends in Modelling Inter-Organizational Cooperation' ((2009) 22(3) Journal of Enterprise Information 275, 293) concluded that ' $[\mathrm{t}] \mathrm{here}$ is a clear trend in business and industry that companies increasingly participate in cooperative networks for their own benefit. These networks may be temporary... or more or less permanent. Either way they are dynamic: during the existence of the network, members may join and leave. In order to meet the requirements and challenges of participating in networks, companies must be able to cooperate effectively and efficiently.'

79 The literal definition of 'alliance' includes 'any joining of efforts or interests by persons, families, states or organisations': The Macquarie Dictionary (2001) 49. The management
} 
sole practitioners spoke of having forged informal alliances, and other practices, with colleagues as a method of dealing with the professional loneliness of the RRR sole practitioner. The most commonly cited benefits of these informal alliances included: being able to hand over and enjoy a holiday and being able to talk over a legal issue. Some practitioners, it seemed, forged these informal alliances far more effectively than others.

\section{E Strategic and Innovative Alliances in RRR Queensland}

As part of the semi-structured interviews, five questions were asked relating to alliances. The questions related to the law practice's existing plans or future plans to ally with firstly, an urban legal practice; secondly, a RRR legal practice; thirdly, a specialist legal practice; fourthly, another professional service firm (for example, an accountant); and, fifthly, with a nonprofessional practice (such as a financial planner).

RRR legal practitioners primarily sought alliances with other RRR legal practices and specialist legal practices, rather than alliances with urban legal practices. However, the qualitative data suggests that the legal practices that were registering highly in terms of 'sustainability' did seek alliances with urban law practices and that this was for the purpose of movement of work in order to gain wider practice areas. ${ }^{80}$

The semi-structured interviews revealed a range of alliances from the loosely cast links described in the following two quotations ...

\footnotetext{
literature states that a strategic alliance 'exists whenever two or more independent organizations cooperate in the development... or sale of ... services': (Jay B Barney and William S Hesterly, Strategic Management and Competitive Advantage: Concepts and Cases (Pearson/Prentice Hall, $2^{\text {nd }}$ ed, 2008) 278. Barney and Hesterly then classify these alliances into non-equity alliances, in which cooperation between firms is managed directly through contracts; joint ventures, in which cooperating firms form an independent firm in which they invest; and equity alliances in which cooperative contracts are supplemented by equity investments by one partner in the other partner. Strategic alliances create value by exploiting opportunities and neutralizing threats facing a firm.

${ }^{80}$ The results were as follows: 31 per cent had an alliance with an urban legal practice, whereas 69 per cent did not have any such future plan; 65.5 per cent currently had such an alliance with a RRR legal practice and 3.4 per cent intended to establish a future alliance; 51.7 per cent had an alliance with a specialist legal practice, and 6.9 per cent planned to establish such a link; 31 per cent had an alliance with another professional service firm (such as an accountant), and 10.3 per cent intended to establish a link; 6.9 per cent had an alliance with a non-professional service firm (such as a financial planner) and 93.1 per cent did not plan to establish a link with non-professionals.
} 
I am mentored by my previous law firm, one of the partners. I still ring him and contact him. I'm also very close to my previous law clerk, X. We still swop knowledge. We swop IT knowledge, legal knowledge. It keeps work fun! (Sole practitioner)

We bounce ideas off other solicitors; we have good relationships with other sole practitioners. (Sole practitioner)

... to the slightly more formally articulated alliances described below.

The alliances with urban legal practices were entered into only by the bigger, older RRR legal practices:

The Brisbane law practice is in the metro CBD. This is showing growth of profit; and experience. The Brisbane office... this does business services; litigation goes out to Brisbane. The regional firm specialises in [practice areas]. (Partner)

Alliances with other RRR practices were far more common amongst both sole practitioners and partnerships:

I have relationships with others in a loose fashion... I 'recommend' them; I work with regional firms to give to clients something I can't provide. (Sole practitioner)

We have big clients in $\mathrm{X}$ and $\mathrm{Y}$ but not in Brisbane. We contemplated $\mathrm{X}$ we have two partners at $\mathrm{X}$ with contact with rural clients. We may pursue this. $\mathrm{X}$ is a lucrative area. We need to get the model right ... then use this as a saleable asset. (Partner)

Alliances with specialist legal practices were also well utilised by both sole practitioners and partnerships:

Yes, with IP areas we work with a patent attorney. We need big clients to sustain this. (Partner)

There is only one other firm who does litigation in X. This relationship we've had for a long time - six years. (Partner)

I refer work to $\mathrm{X}$ - family law and personal injuries. I use him for consulting and talking to on trusts and estates. If I need advice, I prefer to use $\mathrm{X}$ rather than a barrister. They will do a piecemeal job. I will refer for, say, a succession planning and I will learn from it. I use them as a partnership. (Sole practitioner) 
I refer work-place matters; construction and building (sole practitioner).

Alliances that extended beyond other lawyers and into relationships with other professional service firms were also well supported:

We have loose relationships at the moment ... We thought about accountants in an MDP. We get big referrals - non exclusive. (Partner)

I have alliances with accountants, financial planners, lenders and psychologists. (Sole practitioner)

Part of the strategic planning is with alliances - with accountants, engineers, town planners, builders — but non-exclusionary. (Partner)

I also have alliances with accountants. We work very closely together. And with financial planners ... for Centrelink, and I will refer rural work. There is reciprocity. Also real estate agents. (Sole practitioner)

Only a few legal practitioners expressed keenness for independence (a fierce independence) that did not include any alliances:

We have no other alliances and no plans to enter into other alliances. In 10 years I think that the practice will be as it is now. I have no plans to expand any further or to move into either a more urbanised practice, or to pick up more remote work. (Partner)

And, conversely, only one RRR legal practice interviewed reported international alliances. This was, not surprisingly, a legal practice that registered as being both old and large.

In terms of the impact that these alliances made, the participants expressed this in various ways, noting benefits to their practices and also benefits to their sense of well-being.

Amongst the sole practitioners interviewed, a few were clear about why they had chosen sole practice, about the role of the sole practitioner, and about why this structure worked for them. They had actively created strong 'alliances' with previous employers, previous employees, and specialists, as a means of substituting for the benefits of partnership.

The primary benefits flowing from these strategic and innovative alliances (which were an 'imitation of partnership') included: having a method of providing expert legal advice in specialist areas, and therefore retaining clients, minimising the risk of inaccurate legal advice or the mishandling of 
ethical issues; having a method of sourcing clients; and having a means to reduce stress through extended collegiality.

\section{The INNOVATIVE USE OF INFORMATION TECHNOLOGY}

The third part of this paper deals with the innovative use of information technology. In some circumstances this use can assist with forging alliances and can also be a means of retaining valued legal staff.

The legal profession, usually so adept at contemplating and writing about the past, has recently been dwelling on the future. ${ }^{81}$ This part of the paper considers the legal profession literature on the innovative use of technology, and compares its findings with the exploratory research that reveals how and why RRR legal practitioners are using information technology. RRR legal practices, like other businesses, must be aware of the anticipated or predicted future environment in order to adapt to it if they are to remain sustainable. ${ }^{82}$

\section{A Lawyers as 'Providers of Information'}

Susskind, in The Future of Law (1996), accurately forecast the use of information technology in law, and more recently he has questioned whether it will lead to The End of Lawyers? ${ }^{83}$ The underlying premise for Susskind's predictions concerning the impact of information technology for the practice of law is that 'lawyers are in the information business' ${ }^{84}$

Lawyers acquire information through education and training, capture and retain information as part of their stock-in-trade, and sell information to clients who ask for it to be applied to their circumstances. Lawyering is,

\footnotetext{
${ }^{81}$ Legal academics have written much recently on the changing practice of law: Susskind, The Future of Law, above n 14; Susskind, The End of Lawyers?, above n 14; Morgan, above n 14, Mayson above n 14 and Empson, above n 14. Legal practitioners have also contributed to the discussion: Graham Ballard, 'Growth Areas of Practice and IT - The Relationship' (2002) 22(8) Proctor 14; Christine Burns, 'When Will We Be Replaced by 'Virtual Lawyers?' (2000) 38(6) Law Society Journal (New South Wales) 68; Brett Davie and Jan Styles, 'Moving your Law Firm On-Line' (2001) Australian Legal Practice Management Journal 23; and Geraldine Neal 'Cyber-Practice and Parenting: Using IT to Manage Your Greatest Asset' (2002) 22(7) Proctor 15.

82 Paul Hyland and Ron Beckett, 'Engendering an Innovative Culture and Maintaining Operational Balance' (2005) 12(3) Journal of Small Business and Enterprise Development, 336-53.

${ }^{83}$ Susskind, The End of Lawyers?, above n 14, 82.

${ }^{84}$ Ibid 79.
} 
arguably, more information intensive than any other industry or
profession.

It was inevitable, then, that technology would impact on any profession whose function it is to collect information, manage it, and manifest that knowledge and information in advice given to its clientele. Legal practices that were quick to recognise these implications would certainly have an early competitive advantage: ${ }^{86}$

With our business, with our turn over, the product produced is document production. At the end of the day we need a medium [information technology] to provide that to the client. We are in the business of providing high quality advice. (IT manager)

For other law firms, there may be an inertia to overcome.

Some might want to argue that lawyers' conservatism is the key factor here [for the slow take up of IT], an inertia which extends well beyond that of most professionals, and, it might be said, is institutionally enshrined and bolstered in the legal psyche by precedent, the very lifeblood of the common law. ${ }^{87}$

For RRR legal practitioners there may be a double layering of conservatism to be found in both the law, and life in the country. The exploratory findings of the research outlined below reveal both conservatism and optimism in the use of information technology.

There may be valid reasons for hesitancy in using information technology on the grounds that such innovation may be disruptive, or may result in reducing the effectiveness of the practice. ${ }^{88}$ Not all change leads to increasing sustainability and competitive advantage. Additionally, research indicates that an integrated approach to the introduction of innovation, rather than a fragmented approach, can improve performance. ${ }^{89}$ Both points support a strategic approach (rather than a reactive one) to the introduction of information technology.

\footnotetext{
${ }^{85}$ Ibid.

${ }^{86}$ For a discussion of competitive advantage, see Jay Barney, 'Firm Resources and Sustained Competitive Advantage' (1991) 17(1) Journal of Management 99-120.

${ }^{87}$ Susskind, The End of Lawyers?, above n 14, 246.

${ }^{88}$ Hyland and Beckett, above $\mathrm{n} 82$.

${ }^{89}$ Mile Terziovski, 'Achieving Performance Excellence through an Integrated Strategy of Radical Innovation and Continuous Improvement' (2003) 7(2) Measuring Business Excellence, 78-92.
} 
Susskind suggests that the use of information technology by legal practitioners must take into account a number of factors if it is going to provide genuine innovation, and ultimately adaptation, to the changing environment.

Firstly, he suggests that information be used for innovation, not merely automation. This approach will achieve wider business objectives, ${ }^{90}$ such as enabling legal practices to attract legal staff by allowing more flexible working conditions. ${ }^{91}$ Lawyers need to focus their initiatives on what they consider the more beneficial uses of new systems. ${ }^{92}$ For example, they should use information technology for research, improved communications and systematised client file management — rather than mere word processing.

Secondly, he suggests that this strategic use of IT can be a 'major enabler', assisting in the reduction of geographical differences. Susskind himself focusses on international geographical impacts, but geographical impacts can relate just as easily to distances that are within a country, particularly when that country is as enormous as Australia. ${ }^{93}$

Thirdly, Susskind notes that law staff and clients may judge a legal practice on the quality of the information flowing from it through the use of information technology, including the presentation of documents and the 'look and feel' of its website. ${ }^{94}$ This may give an advantage to a RRR legal practice that can have a high quality 'virtual office' on the internet, without the expense of a city lease.

Fourthly, information technology allows small legal practices to group together as single, 'virtual legal practice' under one 'virtual' roof. This feature or impact of the use of information technology has been further pursued by Susskind in his latest publication The End of Lawyers? ${ }^{95}$ in which he predicts

\footnotetext{
${ }^{90}$ Susskind, The End of Lawyers?, above n 14, 227.

${ }^{91}$ The critical issue of attraction, selection, retention and progression of suitably qualified legal staff is complex. This paper proposes the innovative use of information technology as one means of dealing with the issue. It is certainly not the only means. Further research into this issue is being carried out in terms of strategies being used by RRR legal practices. An example of alternative methods that has been taken up by a number of RRR legal practices is the recruitment from within local communities; and the recruitment and training from within legal practices.

92 Tanya du Plessis and Adeline du Toit, 'Knowledge Management and Legal Practice' (2006) 26 International Journal of Information Management 360-71.

${ }^{93}$ Susskind, The End of Lawyers?, above n 14, 227.

${ }^{94}$ Ibid 230.

${ }^{95}$ Ibid 82.
} 
that the role of lawyers is changing due to the impacts of technology. Susskind anticipates that technology will allow small legal practices and sole practitioners to aggregate work, and to stay in the small firm and remain competitive.

There is an argument that adaptation through the use of innovative information technology is more readily available to smaller firms than larger firms on the grounds that they are simpler, cheaper and less complex. ${ }^{96}$ Most of the firms considered in this research study would be classified as 'small' firms.

\section{B An Overview of How Regional Legal Practices Are Using Information Technology}

RRR legal practitioners were asked, during the semi-structured interviews, a number of questions on the use of information technology. They included: 'What information technology is used?'; 'Who uses it?'; 'Who is the innovative user of information technology?'; and 'What training in information technology occurs?'.

\section{Types of Information Technology Used}

Of the 30 RRR legal practitioners interviewed, most principals used some form of information technology. Access to and use of emails ran at 93 per cent; non-subscription databases (for example, Austlii and the Supreme Court Library website) were used by 89.7 per cent; subscription databases (for example, LexisNexis, Leap and LawMaster) were used by 65 per cent; voice recognition technology was used by 51 per cent; Webcam was used by 44.8 per cent. Some legal practices also made use of video-conferencing.

The legal practice's quality of presence on the internet was closely considered: 27.6 per cent of legal practices had a high quality internet presence that included practice areas, staff information, branding, and some form of interaction; 31 per cent had a moderate quality presence in that a website had been designed, yet provided only minimal information. Forty-one per cent did not have a website and relied solely on a referral provided by another source (that is, the Yellow Pages).

\footnotetext{
${ }^{96}$ Ibid 229.
} 


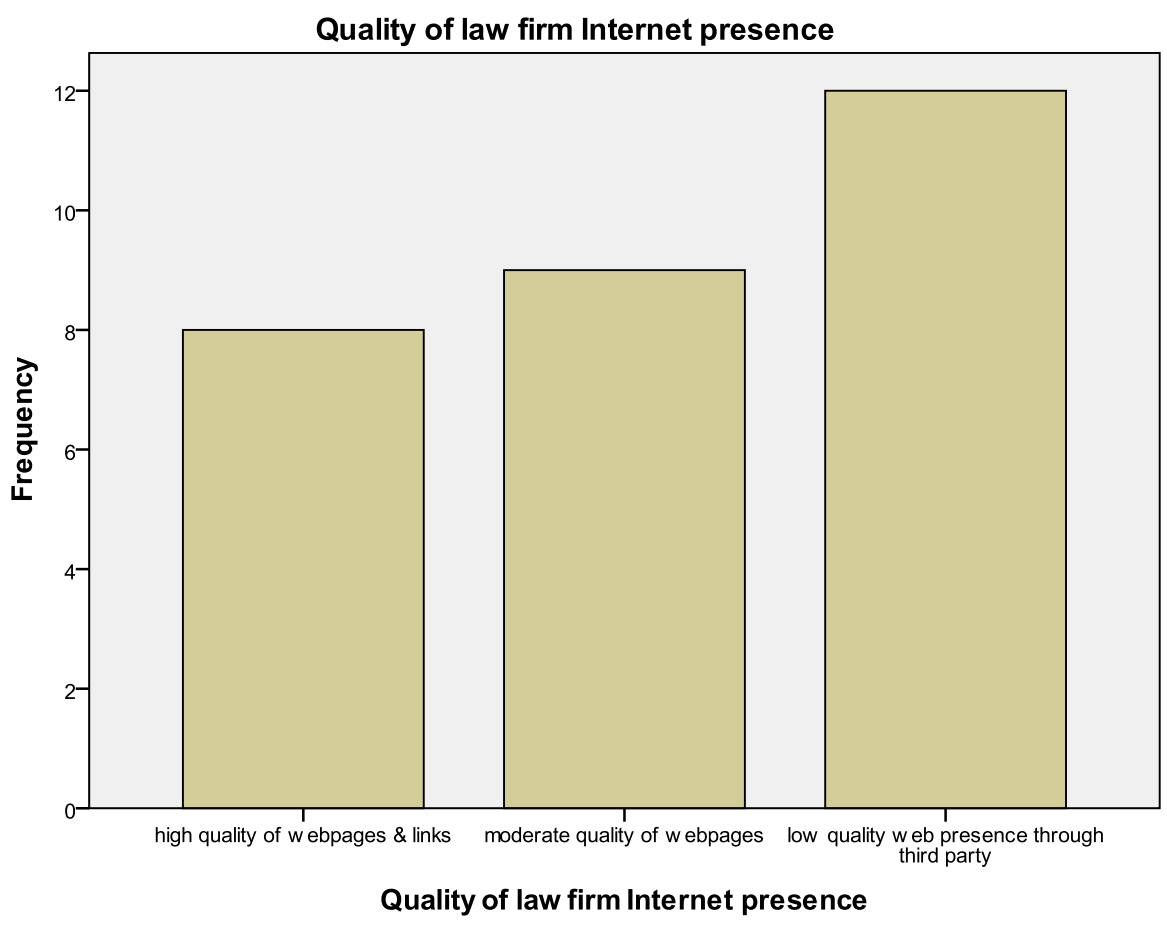

One future impact of the quality of internet presence is that staff and clients will judge law practices by the web, rather than the physical location. ${ }^{97}$ Websites are relatively easy and cheap to design and maintain.

\section{The Users of Information Technology}

The most frequent users of information technology were administrative and para-legal staff. Three interviewees revealed that the principal did not have a computer and did not use emails, that all communication was through the principal's administrative support and via hard copy.

The interviews indicated that the most innovative users of information technology were employed solicitors:

$\mathrm{X}$ [the employed solicitor], with his Bachelor of Computer Science qualification - he's the innovator; he does research online. (Partner)

\footnotetext{
${ }^{97}$ Ibid 249.
} 
Y [the employed solicitor] has his own laptop. Computer systems are not relevant. If Y took over the practice he could overhaul the IT. (Partner)

$\mathrm{X}$ [the employed solicitor] got us onto accessing the non-subscription sites. (Partner)

\section{E How Information Technology Is Being Used by RRR Practitioners}

Within RRR Queensland, there is enormous variation in the use of information technology, apparent from the comments below, with practitioners from all governance structures participating.

The use of information technology can best be represented upon a continuum. That continuum includes: rejection of information technology; absence of information technology; use for mere automation purposes; use for innovative purposes; use for highly innovative purposes. Of those surveyed, 34.5 per cent noted that there were no plans to include information technology in their practice.

\section{Absence of/Minimal Use of Information Technology}

$\mathrm{X}$ does not use IT. His PA types up his hand written work. (Partner, commenting on another partner)

I can cope with other people having them [computers] but I'm not used to it. But others have them. We don't use any legal software. We're using MYOB. We are looking at alternatives. Our trust accounts run as a paper system. We have looked, but it's too expensive. (Partner)

People that start up a practice get the software because they have no confidence. They are relying on software to fill in the gaps. So, when push comes to shove, they can't do it. I use it with caution. (Sole practitioner)

$X$ [name of partner] uses a computer. That won't solve the problems. The problems of the practice are lack of demand. (Partner)

We don't have LEAP or other software for practice management. I use the Family Law Court website. I telephone QLS [for information]. I have tried to use the Electronic Court Lodgement, but I've had difficulty using this. (Sole practitioner)

At the moment I use MYOB for account and banking and trust accounting... precedents.... (Sole practitioner) 
With the computers we are about to embark on LEAP in late July. This is costing me \$25 000. (Sole practitioner)

\section{Moderate Use of Information Technology}

We have email, no website though. All the staff has [sic] a work station. We can research online. X [name of employed solicitor] is big on that. We don't use LexisNexis subscription, but I subscribe to the loose-leaf services on paper. We don't have Leap or Law Master. (Partner)

We set up the video conferencing facilities through the Law Foundation [grant] of $\$ 30000$. We asked to put it in and we have made it available for other practitioners to use it. (Sole practitioner)

LEAP will assist with trust accounting, general accounting. It has 5000 precedents, family court forms, billing - both quotes and time costing... (Sole practitioner)

I've been building the IT resources - putting systems in place. When I bought the business, the IT died. All the customers' information went. I had to rebuild the database. I use Open Practice, because I had used it before. I had relationships with my previous firm that helped fantastically. I was keen to get the practice, but had to modernise it. (Sole practitioner)

I have full remote access. (Sole practitioner)

We use voice recognition technology - that's in the strategic plan. We use web-cam technology for meetings on the web-cam. We don't do electronic lodgement of documents - it's not available at X [name of location]. We can't file claims. (Partner)

We [the partners] meet fortnightly or monthly using video links between $X$ [name of metropolitan location], Y [name of rural location] and Z [name of remote location]. (Partner)

We use a range of IT. We need it to have the $\mathrm{X}, \mathrm{Y}$ and $\mathrm{Z}$ [office] connections. We have networked systems between $\mathrm{X}$ and $\mathrm{Y}$. We have Iphones, e-mails ... they are useful and effective and efficient, but you can get inundated with them. All our legal staff have laptops. All of our staff have desktops. I'd say that three out of four of our partners are very confident at IT. B [a partner] is not so good. TAFE was brought in from T [location] to carry out an IT training day. Our software is updated when needed. As partners we meet once every three months, but we are communicating by emails all the time - it can continue over a week. All the partners are involved; it doesn't matter whether they are in X, Y or Z. (Partner) 


\section{Innovative Uses of Information Technology}

The technology can overcome the population being spread. You have to move with the times and adapt. I have trebled the turnover of the practice. When I came out here [to look at the practice] I saw that the partners three of them - were each making \$200 000. I was earning \$45000 at the time! I turned the business around! (Sole practitioner)We want the best. We don't worry about graduates going or leaving. People go - because if a partner or wife has been transferred. We have a partner in [metropolitan city] who has great interpersonal skills. We can access him remotely. (Partner)

We use video conferencing. Most meetings are on videoconferencing. We have great IT support! (Partner)

We have a solicitor travelling around Europe for a year. He does 15 hours work a week. We have people all over the place. We have a PA who lives in [another state]; a partner in [metropolitan location]. We have job sharing for paralegals. The emphasis is on doing the job and looking after the client. We've kept staff that are valued and valuable. It doesn't matter where you live - you can live in Melbourne. The location is not important. (Partner)

The IT is unbelievable. The speed of service, communication, precedents, documents and research. Our approach is that the IT must be the same - in the office in [metropolitan city]; in Y [rural location]; at home; with the client; or overseas. It gets delivered as the same resource. Every solicitor has a desktop, a lap top, a smart phone - from a console. Our biggest development is the smart phone - staff can monitor files while in court. The attitude with IT is very different. [The law firm's] focus is IT driven. What it can do for us is to drive the business and lessen the risk. The benefit is to the bottom line. Then there is no holding back - it's constant development. Even though we were in the GFC, we kept increasing our profits due to our ability to produce. I don't have an office. (Partner)

\section{F Using Information Technology for Innovation Not Automation}

Among RRR legal practitioners, there was breadth of use of information technology. The level of innovation was not necessarily linked to the sophistication of the technology available to individual practitioners, but rather to how they used the technology. One example is the sole practitioner's use of a Dictaphone and a computer:

I also use digital transcription of documents. I record using a Dictaphone and send as a voice package. (Sole practitioner - sending the documents to administrative support located in Victoria) 
The way in which this sole practitioner used relatively inexpensive technology enabled this legal practitioner to access contracted administrative support at a distant location on terms that suited both parties.

A few legal practices used high quality websites detailing their practice areas, services and staff in terms that were geared to be relevant to the client. Examples of websites designed with the client in mind were most evident in the areas of rural law. Legal practice websites in this area were designed to provide prospective clients with relevant information and action points relating to a range of practice areas, but they were grouped together as 'rural law' - a clear acknowledgement of the client's needs.

Other uses of information technology related to the provision of services to clients at locations convenient to the client. Legal staff travelled to the clients with laptops fully fitted with files, precedents and access to research as a means of replicating the resources that would usually be available at the physical office.

Importantly, information technology was also used to attain a broader objective, that is, to attract and retain valued and valuable legal staff. In some instances partners and employed solicitors were provided with laptops and software that would enable working from home and working while travelling. This provided flexible working conditions that resulted in retaining 'star' legal staff.

[Name of partner] moved to Brisbane, and spends only some of his time at [location of law firm] and [second location of law firm]. Again this was accommodated because the firm values the partner. With the IT available i-phone emails, and so on - he is always available. Distance is no longer a tyranny. (Partner)

Information technology was also used to outsource specific administrative functions. In some cases the outsourcing involved immense geographical separation from the physical location of the legal practice - for example, in other states and over thousands of kilometres away. 


\section{G Critical Factors for the Innovative Use of Information Technology}

The use of information technology, to be effective and to enhance sustainability, should take into account 'critical factors' ${ }^{98}$ including the need for strategy, user involvement, and hybrid management.

\section{Need for Strategy}

'Without strategy and planning, investment in IT is destined to be illconsidered, haphazard and disappointing in its results. ${ }^{, 99}$ From the semistructured interviews, only 34 per cent of interviewees indicated that the use of information technology was part of their business planning. Ten per cent of principals indicated that they 'read journals' to source information on the use of information technology; and 17 per cent reported that they had relied on an information technology consultant to assist with their use of information technology.

\section{User Involvement}

To gain the desired results from technological innovations, users need to be trained and educated to understand and accept the benefits available. Management should aim for a culture in which users can directly see those benefits; and they should be involved, appropriately, in the decision-making process. ${ }^{100}$ Training on the use of information technology was frequently neglected. ${ }^{101}$ Sixty-two per cent of principals spoke of including moderate training as part of their use of information technology, whilst only a few principals reported training as a priority:

TAFE was brought in from $\mathrm{T}$ [location] to carry out an IT training day. Our software is updated when needed. (Partner)

\section{Hybrid Management}

A common issue in the legal profession is the lack of properly qualified information technology staff to assume the responsibility for the use of information technology. ${ }^{102}$ Often, it is the 'enthusiastic evangelistic IT

\footnotetext{
${ }^{98}$ Susskind, The End of Lawyers?. above n 14, 223-67.

${ }^{99}$ Ibid 234.

${ }^{100}$ Ibid 236.

${ }^{101}$ Ibid 238.

${ }^{102}$ Ibid.
} 
amateur' who makes the decisions about the use of information technology. In RRR legal practices, it appears that it is the employed solicitor who is responsible for information technology management. The uses to which information technology is put are not always well researched nor do they necessarily fit strategically within the business planning. However, there were some notable exceptions among the RRR legal practitioners whose foresight in researching and engaging in the use of information technology had enormous impacts on the sustainability of the practice.

I do systems work. In the legal business, how many staff do you need before you can justify an IT person? With an IT manager, we can now run training programs, risk management, induction programs. This is an example of the processes ... needed for the staff. X [name of law firm] has that focus because we can deliver the product well. We got quicker and smarter as a result of staff training and IT — and improving this by having the system. A regional law firm needs IT more than a CBD law firm. In the region though you are stuck with the slow speed! (Partner)

\section{H Benefits}

The benefit of using information technology innovatively is that it offers legal practices an opportunity to attract and retain valuable legal staff through offering a flexible work environment, and enabling the movement of lawyers between regional, rural, remote and urban locations.

'IT is challenging some of our fundamental assumptions about where we should physically locate our organisations. ${ }^{, 103}$ It is capable of 'bringing an entire, geographically dispersed workforce under the one - albeit virtual roof. ${ }^{104}$ Susskind's prediction is that the innovative use of information technology will enable organisations to retain their productivity (and market share) by being able to retain their high-powered/valuable staff. ${ }^{105}$

A firm's source of strength will not, as it was in the past, be in its rigid adherence to structure and stability; rather it will be in its flexibility and adaptability and its ability to take the organisation through these times of continuing change... ${ }^{106}$

\footnotetext{
${ }^{103}$ Ibid 248.

${ }^{104}$ Ibid 249.

${ }^{105}$ Ibid.

${ }^{106}$ Ibid 250.
} 
It will most likely not be the only means available to RRR legal practices to improve staff attraction and retention. The research (and its analysis) is ongoing and revealing other data on this topic.

\section{Linking Strategic Alliances with Innovative Use of Information Technology}

The combination of physical strategic alliances with the virtuality of information technology is one means of not only adapting to, but profiting and growing through the opportunities offered.

RRR legal practices need to consider information technology as an opportunity for creating the environment in which lawyers (in particular young lawyers) want to work. Staff and clients of the future will judge law practices by the web, rather than the physical location. ${ }^{107}$ The converse of that statement is that clients and staff may judge negatively a regional legal practice that does not take its web presence seriously.

\section{BARRIERS TO THE INNOVATIVE USE OF INFORMATION TECHNOLOGY}

The results of the interviews with principals and directors of legal practices reveal a number of barriers to information technology uptake that can readily be dealt with by policy makers and infrastructure providers.

Firstly, RRR legal practitioners expressed dismay and concern that their efforts to use e-lodgements of documents with courts were not supported by the courts. The result was that the costs of poorly serviced e-lodgements were put back onto the individual practitioners who could ill-afford to make up for the shortfall.

Nowadays all stamping is by the web. This causes work. All the details are put in by the law firm. This shifts the work back to the law firms. There are 3 staff in [location of court house] ... 5 in [location of another court house]... But I write to them that they need to do it right, otherwise there are issues. This adds to the stress. And there are work issues on my staff... (Sole practitioner)

We don't do electronic lodgement of documents. It's not available at [location of court house] — we can't file claims. (Partner)

${ }^{107}$ Ibid 249. 
I have tried to use the Electronic Court Lodgement, but I've had difficulty using this. (Sole practitioner)

The IT infrastructure at the court is not as good. (Sole practitioner)

Secondly, the physical infrastructure supporting the internet is poorly serviced and maintained as a factor of distance from metropolitan centres.

The speed is an issue. This is a cost and a limitation. The exchange won't deal with it. They need to change the boundaries. [Location of practice] is considered remote! How IT governance is considered is through regional classifications. The [location of practice] Exchange is old! It's analogue. (IT Manager)

We recently installed LEAP. With the LEAP software, the practice's cabling was so old, we needed to re-cable (Sole practitioner)

As areas become bigger, law firms do get serviced, but not until the service comes to town. These firms need a fake office in [regional location] where the IT services could be provided. (Partner)

Thirdly, information and knowledge about information technology resources and uses are poor.

The QLS doesn't recommend a computerised system. It would be good if the QLS could provide an endorsement of a few of them dealing with trust accounting - if they could put that information on the internet. (Partner)

Another sole practitioner expressed a keenness to find out about funding options available to support her installation of video-conferencing technology at her practice.

\section{Recommended Actions}

On the basis of the foregoing findings, the following actions are recommended.

Firstly, further research into the use of 'alliances' by RRR legal practitioners needs to be carried out to determine how and why these relationships may support practitioners in adequately providing services to clients and in providing collegiality. 
Secondly, professional organisations need to promote the use of, and benefits to be gained from, the information technology. These organisations also need to provide guidance and assistance in decision-making. Older RRR principals are less experienced (and less confident) in their use of technology than younger ones. Organisations that they look to for professional support can assist with confidence-building and decision-making.

Thirdly, governments must improve funding of, and support for, the courts' use of information technology, including e-lodgement. The poorly funded and serviced use of the technology by government agencies is currently being borne by RRR principals and directors who cannot afford the costs.

Finally, governments and service providers must improve infrastructure and services to assist with the efficient and effective use of information technology in RRR locations. The take-up of technology by RRR legal practitioners is a frustrating experience in those circumstances where the infrastructure does not support its use. 